
A C T A

Andrzej WITKOWSKI, Jan BEACHUTA, Jolanta OLESIŃSKA

Fish biology

\title{
AGE AND GROWTH-RATE OF GRAYLING THYMALLUS THYMALLUS (L.) IN THE RIVERS OF POMERANIA (NW POLAND)
}

\author{
WIEK I TEMPO WZROSTU LIPIENIA THYMALLUS THYMALLUS (L.) \\ W RZEKACH POMORZA
}

Wrocław University

The studies were carried out on the material of 308 individuals from 18 upland rivers of moraine character, in north-western Poland. The growth rate, growth intensity, condition factor and the dependence between body weight and total length were estimated. It has been found that the graylings from north-western Poland live longer ‘and grow quicker than those from mountain rivers in southern regions of the country, and also in other parts of Europe.

\section{INTRODUCTION}

The European grayling Thymallus thymallus (L.) is among fishes of high habitat requirements. It is regarded as species indicative of pure water, since it is little resistant to even slight pollution (Witkowski et al. 1984). Besides, it does not tolerate higher water temperatures (over $20^{\circ} \mathrm{C}$ ), both during its embryogenesis and other periods of life (Humpesch 1985, Kokurewicz et al. 1980). Because of this it lives in pure, cold and very well oxygenated waters, being confined to submontane and partly mountain rivers (grayling zone). 
For the reasone just named, the occurrence of the species in Poland is limited to two areas: southern, including some Carpathian and Sudetic rivers, and northern, where it is found in most rivers of Pomerania. On account of its high angling importance it has been recently introduced to many rivers in which it either did not occur originally, or was extinct earlier (Witkowski et al. 1984).

The growth-rate of grayling in Poland has been comparatively poorly studied. Only a few populations from the south of Poland have been studied in this respect: from the river Dunajec and its tributaries, from Soła, Nysa Kłodzka and Kaczawa (Błachuta 1987, Gertychowa 1976, Krajewski 1986, Solewski 1960, 1963, Witkowski 1975). The information on grayling from Pomeranian rivers is still scarcer. Only Penczak et al. (1986) studied the growth of this species in two rivers of the Gwda basin, and Iwaszkiewicz (1962) attempted an estimate of the fertility and age of graylings from several rivers of that region. The objective of this study was to ascertain the growth-rate and age of grayling in most rivers of that area which, besides. its scientific value, may also be of practical importance, as it allows a rational management of the species. Apart from this, it enables an estimate of the environment pressure, and a detailed description of habitats to which grayling is best adapted (Błachuta 1987).

\section{MATERIAL AND METHODS}

For the analysis of the growth-rate and estimate of age, 308 graylings were used, caught in 18 Pomeranian rivers in 1958-1987. The localization of the rivers is presented in fig. 1. More detailed data on the origin, number and length of fish are summarized in tab. 1 .

The fish were caught using angling rod. Their total length (T1) was measured to the nearest $1 \mathrm{~mm}$, and they were weighed with an accuracy of $1 \mathrm{~g}$. Of each specimen several scales were taken from the first two rows abowe the lateral line, between the dorsal and the adipose fin. This is the place where first scales are formed, and their size is the most correlated with the gryling length (Błachuta etal. 1986). Like in the studies of Blachuta (1987) the radius of annual rings and that of scales were measured in latero-dorsal line of the scales.

The body length for particular years of life was calculated using the methods of back calculation of $E$. Lea. In order to ascertain the size of increment in consecutive years, the following formula wasused: $d T l=T l_{n}-T_{n-1}$, where $T 1_{n}-$ length in the nth year of life, $\mathrm{Tl}_{\mathrm{n}-1}$ - length in the preceding year. In the comparative analysis of growth, the method proposed by Beverton and Holt (1957) was applied, according to von Bertalanffy's formula: $L t_{t}=L t\left(1-e^{-k / t-t_{0}}\right)$, where $L t_{t}-$ total length attained at $t$ age, $L t-$ hypothetical ultimate length, $e-$ base of natural logarithm, $t-$ fish age, $t_{0}-$ hypothetical value of the origin of growth curve, $\mathrm{k}$ - power parameter. Changes in the intensity of growth were estimated using the coefficient of growth characteristics: 


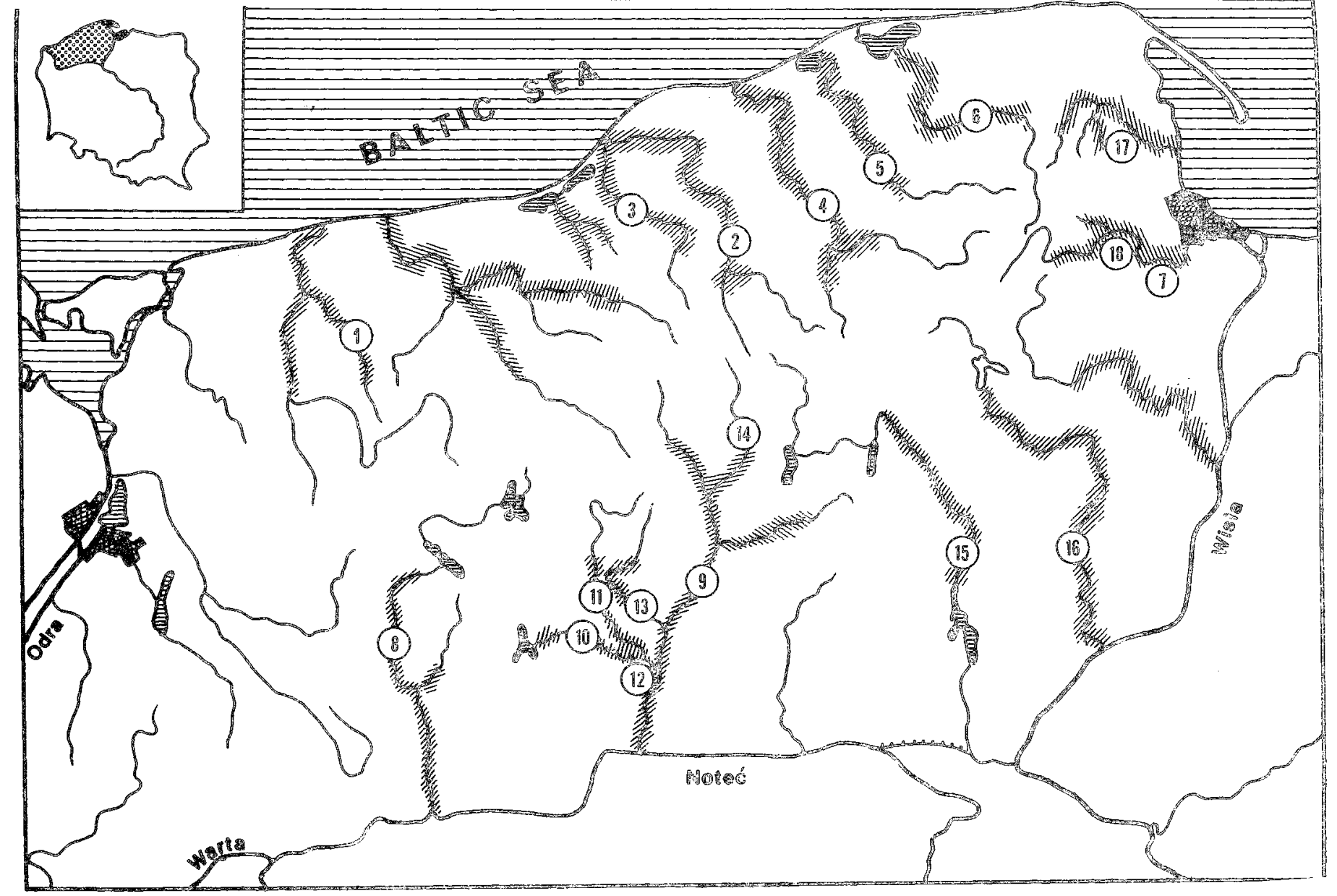

Fig. 1. Grayling rivers of Pomerania. Tivers numbered 1-18 are those from which the material came, detailea data in talo. 1. 
Table 1

List of the grayling material from Pomeranian rivers used for the studies

\begin{tabular}{|c|c|c|c|c|}
\hline No & River & $\mathrm{n}$ & $\mathrm{Tl}(\mathrm{mm})$ & Sampling data \\
\hline 1 & Mołstowa & 3 & $290-350$ & 1966 \\
\hline 2 & Wieprza & 9 & $330-380$ & 1977 \\
\hline 3 & Grabowa & 35 & $232-405$ & 1958 \\
\hline 4 & Słupia & 3 & $300-410$ & 1977 \\
\hline 5 & Eupawa & 6 & $188-345$ & 1976,1977 \\
\hline 6 & Eeba & 11 & $220-340$ & $1974,1976,1977,1983$ \\
\hline 7 & Radunia & 47 & $290-400$ & $1974,1976,1977,1984$ \\
\hline 8 & Drawa & 6 & $310-390$ & $1977,1985,1986$ \\
\hline 9 & Gwda & 27 & $310-440$ & 1983,1984 \\
\hline 10 & Dobrzyca & 25 & $238-485$ & $1977,1986,1987$ \\
\hline 11 & Piława & 5 & $300-360$ & 1986 \\
\hline 12 & Połączone & 35 & $300-480$ & 1986,1987 \\
\hline 13 & Płytnica & 1 & 315 & $?$ \\
\hline 14 & Czernica & 36 & $202-410$ & 1986,1987 \\
\hline 15 & Brda & 24 & $213-440$ & 1986,1987 \\
\hline 16 & Wda & 30 & $252-460$ & $1977,1985,1987$ \\
\hline 17 & Gościnka & 1 & 315 & 1976 \\
\hline 18 & Supina & 4 & $300-350$ & 1974 \\
\hline
\end{tabular}

$\mathrm{C}=\lg \mathrm{T}_{\mathrm{n}}-\lg \mathrm{T} \mathrm{n}_{\mathrm{n}-1} / 0.4343 \mathrm{~T} l_{\mathrm{n}}$, where $\lg \mathrm{Tl}$ and $\lg \mathrm{T} 1_{\mathrm{n}-1},-$ common logarithm of fish length attained in a given and preceding year of life. Values condition coefficient (K) were calculated from the equation: $\mathbb{K}=\mathrm{w} 100 / \mathbb{T} 1^{3}$, where, $\mathrm{W}$ - fish weight in $\mathrm{g}, \mathrm{Tl}$ - total length in $\mathrm{cm}$. The dependence between the weight changes (w) and the fish length (Tl) was calculated according to the formula $\mathrm{w}=\mathrm{a} T \mathrm{l}^{\mathrm{b}}$, using its logarithmic form: $\lg \mathrm{w}=\lg \mathrm{a}+\mathrm{b} \lg \mathrm{T} 1$, where $\mathrm{a}$ and $\mathrm{b}-$ constant values calculated from empirical data.

\section{STUDY AREA}

Pomerania, called also Pomeranian Lake District, is situated in the north-western part of Poland. In the north it is bordered by the Baltic Sea, in thesast by the Vistula river, in the south - the lower section of the river Brda, the Notec and the lower Warta, in the west - the river Odra. The àrea is $48000 \mathrm{~km}^{2}$. It lies within the limits of the last glaciation. The latter resulted in a typically moraine landscape. Lakes occupy c. $700 \mathrm{~km}^{2}$, the river system is also exceptionally dense, its characteristic feature being large slopes which gives the rivers a submontane character (Kondracki 1980). Both lakes and rivers still have water of the highest quality class which enables existence of many rare fish and lamprey species (e.g. Lampetra fluviatilis, L. planeri, Salmo salar, S. trutta trutta, S. trutta 
fario, S. trutta lacustris, Coregonus albula, C. lavaretus, Phoxinus phoxinus, Moroco percnurus, Cottus gobio (Rembiszewski, Rolik 1975). The grayling is common and abundant in most rivers. According to Witkowski et al. (1984) the area of Pomerania constitutes its main distribution centre, as the species inhabits $1745 \mathrm{~km}$ of the rivers which accounts for $64.5 \%$ its distribution area in Poland.

\section{RESULTS}

The age of studied graylings ranged from $1^{+}$to $6^{+}$years. Of the age groups fish three $\left(2^{+}\right)$and four $\left(3^{+}\right)$years old were the most numerous, constituting 44.48 and $29.22 \%$, respectively. With increasing age, the number of individuals per age class decreased. The oldest, seven years old $\left(6^{+}\right)$fish was recorded in the material from (rivers Pilawa and Dobrzyca), but it constituted only $0.32 \%$ of all studied individuals. The percentage of fish in particular age classes for each population is presentediuin tab.2,

Table 2

Age structure of grayling from Pomeranian rivers

\begin{tabular}{|c|c|c|c|c|c|c|c|c|}
\hline \multirow{2}{*}{ No } & \multirow{2}{*}{ River } & \multirow{2}{*}{$\mathrm{n}$} & \multicolumn{6}{|c|}{ Age } \\
\hline & & & $1^{+}$ & $2^{+}$ & $3^{+}$ & $4^{+}$ & $5^{+}$ & $6^{+}$ \\
\hline 1 & Molstowa & 3 & & & 3 & & & \\
\hline 2 & Wieprza & 9 & & 4 & $\mathbb{1}$ & 4 & & \\
\hline 3 & Grabowa & 35 & 3 & 19 & 9 & 3 & 1 & \\
\hline 4 & Słupia & 3 & & 3 & & & & \\
\hline 5 & Eupawa & 6 & 1 & 5 & & & & \\
\hline 6 & Eeba & $\mathbb{1}$ & 2 & 8 & $\mathbb{1}$ & & & \\
\hline 7 & Radunia & 47 & 2 & 31 & 10 & 2 & 2 & \\
\hline 8 & Drawa & 6 & & 2 & 2 & 2 & & \\
\hline 9 & Gwda & 27 & & 8 & $\mathbb{1} 1$ & 6 & 2 & \\
\hline 10 & Dobrzyca & 25 & 1 & 10 & 9 & 4 & 1 & \\
\hline 11 & Piława & 5 & & & $\xi$ & & & \\
\hline 12 & Połączone & 35 & 5 & 11 & 10 & 3 & 5 & 1 \\
\hline 13 & Płytnica & 1 & & & 1 & & & \\
\hline 14 & Czernica & 36 & 10 & 16 & 8 & 2 & & \\
\hline 15 & Brda & 24 & 3 & 14 & 1 & 2 & 4 & \\
\hline 16 & Wda & 30 & 1 & 4 & 16 & 7 & 2 & \\
\hline $\mathbb{1 7}$ & Gościnka & $\mathbb{1}$ & & 1 & & & & \\
\hline 18 & Supina & 4 & & 3 & 1 & & & \\
\hline$\Sigma$ & & 308 & 28 & 139 & 88 & 35 & 17 & 1 \\
\hline$\%$ & & 100.0 & 9.1 & 45.1 & 28.6 & 11.4 & 5.5 & 0.3 \\
\hline
\end{tabular}


Length $\mathrm{Tl}(\mathrm{mm})$ reached by grayling from Pomeranian rivers in consecutive years of life. Numerator represents mean value, denominator - range

\begin{tabular}{|c|c|c|c|c|c|c|c|}
\hline No & River ${ }^{\text {Length }}$ & $\mathbb{T} \mathbf{l}_{1}$ & $\mathrm{Tl}_{2}$ & $\mathbb{T l}_{3}$ & $\mathrm{Tl}_{4}$ & ${ }]_{5}$ & $\mathbb{T}_{6}$ \\
\hline \multirow{2}{*}{1} & \multirow{2}{*}{ Mołstowa } & 226 & 295 & 295 & & & \\
\hline & & $225-229$ & $\overline{225-311}$ & $225-311$ & & & \\
\hline \multirow{2}{*}{2} & \multirow{2}{*}{ Wiepra } & 127 & 266 & 310 & 346 & & \\
\hline & & $94-164$ & $\overline{188-327}$ & $279-320$ & $316-356$ & & \\
\hline \multirow{2}{*}{3} & \multirow{2}{*}{ Grabowa } & 120 & 238 & 311 & 352 & 376 & \\
\hline & & $91-158$ & $180-277$ & $290-366$ & $\overline{325-371}$ & & \\
\hline \multirow{2}{*}{4} & \multirow{2}{*}{ Słupia } & 129 & 246 & 354 & & & \\
\hline & & $117-137$ & $222-268$ & $\overline{326-383}$ & & & \\
\hline \multirow{2}{*}{5} & \multirow{2}{*}{ Lupawa } & 129 & 248 & & & & \\
\hline & & $\overline{111-152}$ & $223-279$ & & & & \\
\hline \multirow{2}{*}{6} & \multirow{2}{*}{$\mathbb{E} e b a$} & 121 & 234 & 278 & & & \\
\hline & & $\overline{112-137}$ & $212-257$ & 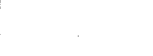 & & & \\
\hline \multirow{2}{*}{7} & \multirow{2}{*}{ Radunia } & .122 & 228 & 294 & 333 & 371 & \\
\hline & & $\overline{95-171}$ & $\overline{190-286}$ & $276-327$ & $\overline{314-364}$ & $\overline{360-382}$ & \\
\hline \multirow{2}{*}{8} & \multirow{2}{*}{ Drawa } & 137 & 255 & 305 & 375 & & \\
\hline & & $\overline{124-159}$ & $225-293$ & $280-323$ & $363-367$ & & \\
\hline \multirow{2}{*}{9} & \multirow{2}{*}{ Gwda } & 135 & 240 & 312 & 349 & 402 & \\
\hline & & $97-195$ & $168-303$ & $241-375$ & $290-394$ & $383-421$ & \\
\hline 10 & Dobreyca & $\frac{142}{122-179}$ & $\frac{257}{197-300}$ & $\frac{322}{261-354}$ & $\frac{388}{357-416}$ & 443 & \\
\hline \multirow{2}{*}{11} & \multirow{2}{*}{ P证 awa } & 139 & 199 & 287 & & & \\
\hline & & $\overline{111-186}$ & $\overline{154-248}$ & $251-322$ & & & \\
\hline \multirow{2}{*}{12} & \multirow{2}{*}{ Polączone } & 159 & 273 & 346 & 399 & 452 & 419 \\
\hline & & $98-200$ & $182-328$ & $296-387$ & $353-408$ & $391-463$ & \\
\hline $\mathbb{1} 3$ & Plytnica & 108 & 176 & 243 & & & \\
\hline \multirow{2}{*}{13} & \multirow{2}{*}{ Czernica } & 159 & 286 & 351 & 354 & & \\
\hline & & $110-189$ & $230-346$ & $297-385$ & $332-375$ & & \\
\hline \multirow{2}{*}{19} & \multirow{2}{*}{ Brda } & 129. & 243 & 313 & 365. & 402 & \\
\hline & & $80-173$ & $173-288$ & $273-347$ & $\overline{323-393}$ & $379-426$ & \\
\hline \multirow{2}{*}{16} & $w \mathrm{da}$ & 143 & 243 & 304 & 369 & 419 & \\
\hline & & $106-203$ & $201-310$ & $264-379$ & $329-414$ & $393-445$ & \\
\hline 17 & Gościnka & 105 & $19 \%$ & & & & \\
\hline 18 & Supina & 122 & 231 & 303 & & & \\
\hline
\end{tabular}




\section{Growth rate}

The growth rate of grayling in the studied rivers is presented in tabs 3 and 4 , and in figs 2 and 3.

Mean total lengths (Tl) attained in consecutive years of life in all the studied populations are as follows: 1 st year - 131 , 2nd year - 238, 3rd year - 308, 4th year 363 , 5th year - 409, and 6th year -419 . The best increments are reached in the first two years of life and amount to 131 and $107 \mathrm{~mm}$, respectively. In subsequent years they range from 68 to 44 mm. Populations from Polaczone (Pi?awa + Dobrzyca), Dobrzyca, Czernica and Drawa are characterized by decidedly quickest grow th. Those from the smallest rivers of the studied area - plymica, Gościnka and Supina - have the lowest Erowth rate.

The length attained by graylings in the first year of life are very similar in most populations. They range from 120 to $130 \mathrm{~mm}$. Omly fish from Tobryca and Czemica are distincty larger (159 mm T1), and those from Prytrica and Gościnka - smaller (108 $\operatorname{man}^{2}$ $105 \mathrm{~mm}$, respectively). In the second year of life, and especially in the third, the grown in the Poneranian populations is more diversifed. In subsequent years (4tin and 5th) the differences are smaller, though this results probably from the scarcity of material, as the fish of those age classes were few. The grow th curves (von Bextalanfy's equation) enabled

Tench

Increase in total length (TI) as \% length in the first year

\begin{tabular}{|c|c|c|c|c|c|c|}
\hline No & River & $\mathbb{T} 1_{\mathbb{1}}$ & $\mathbb{I}_{2}$ & $\mathrm{Tl}_{3}$ & $\mathbb{T}_{4}$ & $\mathrm{Tl}_{5}$ \\
\hline 1 & Molstowa & 100.0 & 69.9 & 51.8 & & \\
\hline 2 & Wieprza & 100.0 & 109.4 & 34.6 & 28.3 & \\
\hline 3 & Grabowa & 100.0 & 98.3 & 60.8 & 34.1 & 20.0 \\
\hline 4 & Słupia & $100.0^{\circ}$ & 90.6 & 83.7 & & \\
\hline 5 & ¿upawa & 100.0 & 92.2 & & & \\
\hline 6 & $\mathbb{E}$ eba & 100.0 & 93.3 & 36.3 & & \\
\hline 7 & Radunia & 100.0 & 86.8 & 54.1 & 32.0 & .31 .1 \\
\hline 8 & Drawa & 100.0 & 86.1 & 36.4 & 51.1 & \\
\hline 9 & Gwda & 100.0 & 77.7 & 53.3 & 27.4 & 39.2 \\
\hline 10 & Dobrzyca & 100.0 & 80.1 & .45 .7 & 46.4 & 38.7 \\
\hline 11 & $\mathbb{P}$ iława & 100,0 & 43.1 & 63.3 & & \\
\hline 12 & Połączone & 100.0 & 71.7 & 45.9 & 33.3 & 33.3 \\
\hline 13 & Płytnica & 100.0 & 62.9 & 62.0 & & \\
\hline 14 & Czernica & 100.0 & 79.8 & 40.8 & 1.8 & \\
\hline 15 & Brda & 100.0 & 88.3 & 54.2 & $40 . \overline{3}$ & 28.6 \\
\hline 16 & Wda & 100.0 & 69.9 & 42.6 & 45.4 & 34.9 \\
\hline 17 & Gościnka & 100.0 & 87.6 & & & \\
\hline 18 & Supina & 100.0 & 89.3 & 59.0 & & \\
\hline
\end{tabular}




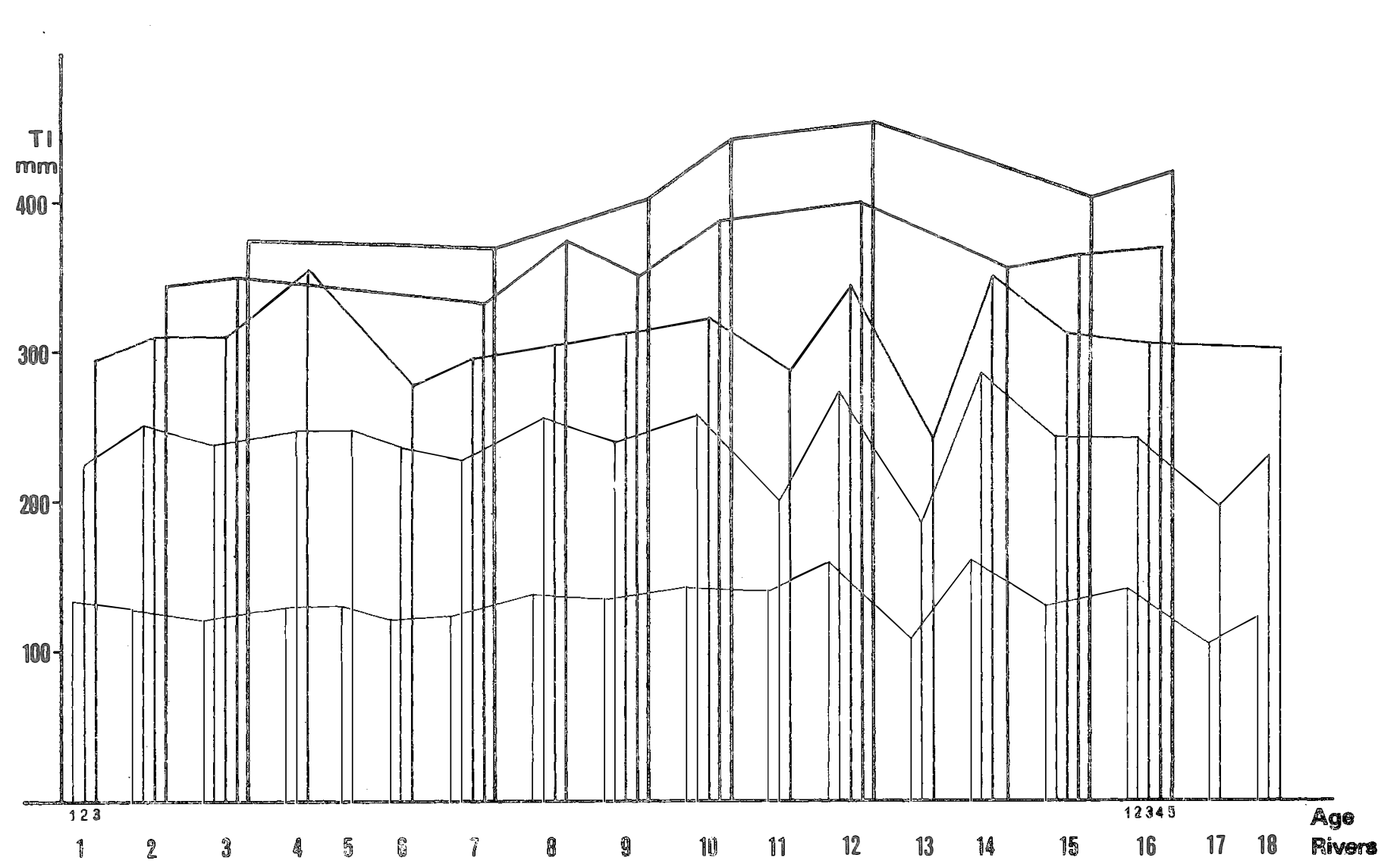

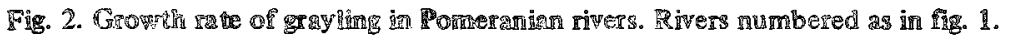




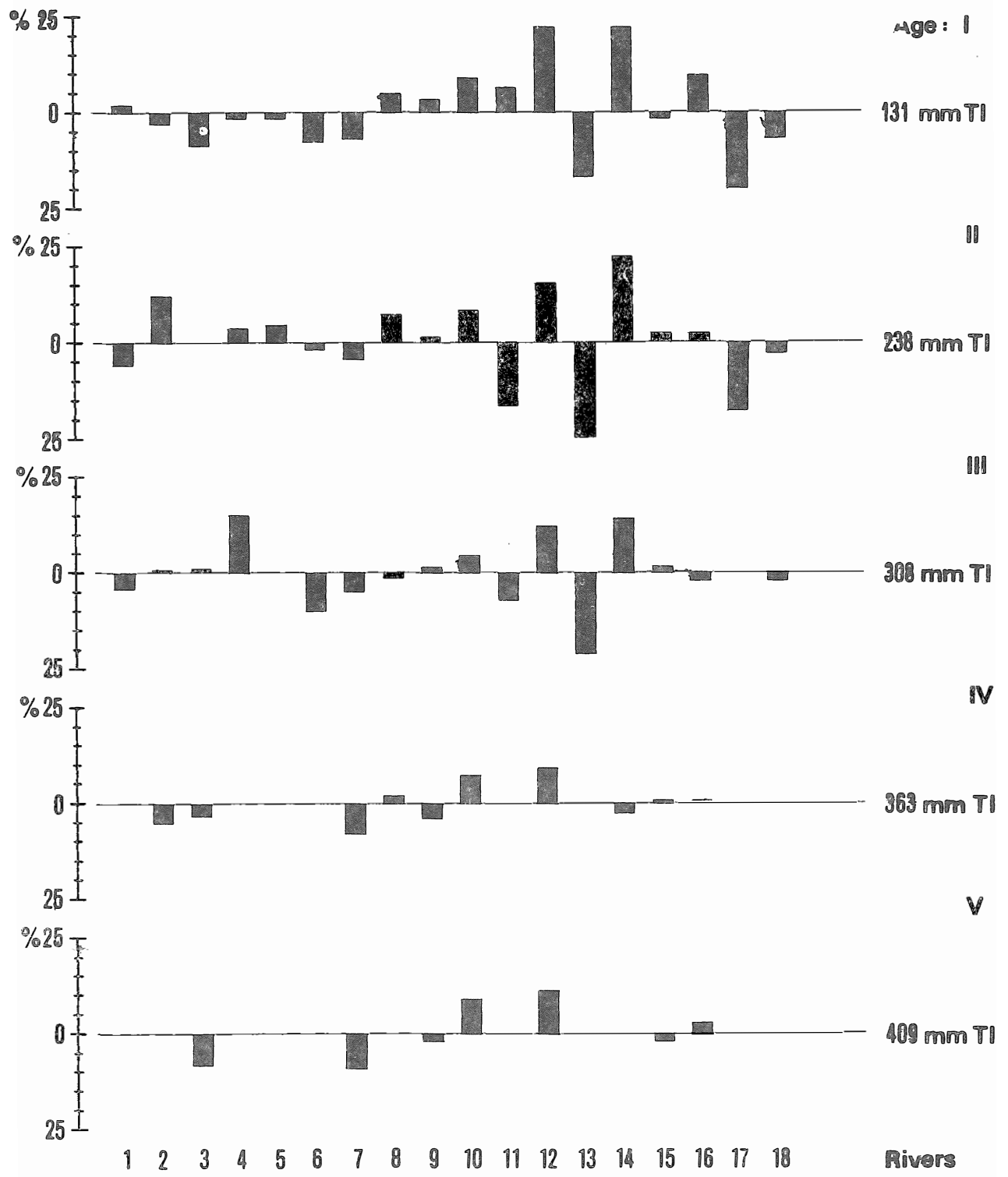

Fig. 3. Deviation (\%) from mean growth rate for particular age classes in the studied grayling populs tions. Rivers numbered as in fig. 1 and tab. 1. 
Parameters of the von Bertalanffy equation characterizing linear growth and hypothetical total lenght at age 3 years $\left(\mathrm{L}_{3}\right)$ of gray lings from Pomeranian rivers

\begin{tabular}{|c|l|r|r|r|r|}
\hline No & River & $\mathbb{L}$ & $\mathbb{K}(-\ln \mathrm{k})$ & $\mathfrak{t}^{\mathrm{O}}$ & $\mathrm{L}_{3}$ \\
\hline 1 & Mołstowa & 525 & 0.269 & -0.20 & 303 \\
2 & Wieprza & 4.5 & 0.397 & 0.13 & 302 \\
3 & Grabowa & 430 & 0.468 & 0.18 & 315 \\
4 & Słupia & 593 & 0.312 & 0.30 & 338 \\
5 & Lupawa & 773 & 0.204 & 0.10 & 345 \\
6 & Leba & 400 & 0.481 & 0.30 & 291 \\
7 & Radunia & 444 & 0.378 & 0.06 & 298 \\
8 & Diawa & 428 & 0.502 & 0.40 & 312 \\
9 & Gwda & 525 & 0.294 & -0.11 & 314 \\
10 & Dobrzyca & 619 & 0.252 & -0.07 & 333 \\
12 & Połączope & 556 & 0.321 & -0.03 & 346 \\
14 & Czernica & 413 & 0.695 & -0.15 & 367 \\
15 & Brda & 505 & 0.341 & 0.01 & 323 \\
16 & Wda & 614 & 0.219 & -0.23 & 311 \\
18 & Supina & 441 & 0.418 & 0.22 & 303 \\
\hline
\end{tabular}

a comparison of the length attained by the graylings of the Pomeranian rivers at a given age. For practical reasons the length in the third year of life was compared (tab. 5), since at that age must Central European populations reach sexual maturity. It follows from the comparison that most Pomeranian graylings start their first spawning after having attained the legal size which in Poland amounts to $300 \mathrm{~mm} \mathrm{Tl}$.

\section{Growth intensity}

The growth of grayling expressed as coefficient of growth characteristics $(\mathbb{C})$ shows marked differences between particular age groups. The highest mean values (4.92-9.93) were recorded among fish aged $1-3$. In subsequent years the values decrease gradually and are the lowest in the oldest individuals -5 and 6 years old (2.70). Probably the variation in the coefficient, like in other fish species, is associated with the grayling life cycle. Until reaching sexual maturity (3rd year) the growth of fish is very quick. In the 3rd year it is distinctly lower and more stabilized. In senile period (over 4 years) it is decidedly the lowest. Mean values of the growth intensity coefficient for all the studied populations are presented in tab. 6.

\section{Condition coefficient}

Mean values of condition coefficient $(\mathbb{K})$ ranged from 0.7 to 1.14 . They were decidedly the highest (above 1.0) in the population of the Gwda basin (Dobrzyca, 
Growth characteristics $(C)$ in grayling from Pomeranian rivers

\begin{tabular}{|c|l|c|c|c|c|c|}
\hline No & River & $\mathrm{C}_{1} / \mathrm{C}_{2}$ & $\mathrm{C}_{2} / \mathrm{C}_{3}$ & $\mathrm{C}_{3} / \mathrm{C}_{4}$ & $\mathrm{C}_{4} / \mathrm{C}_{5}$ & $\mathrm{C}_{5} / \mathrm{C}_{6}$ \\
\hline 1 & Mołstowa & 7.01 & 6.02 & & & \\
2 & Wieprza & 9.33 & 7.29 & 3.58 & & \\
3 & Grabowa & 8.20 & 6.26 & 3.83 & 4.74 & \\
4 & Słupia & 8.33 & 7.88 & & & \\
5 & Lupawa & 8.33 & & & & \\
6 & Leba & 8.04 & 5.38 & & & \\
7 & Radunia & 7.62 & 6.36 & 3.37 & 2.18 & \\
8 & Drawa & 8.52 & 5.38 & 4.12 & & \\
9 & Gwda & 7.66 & 6.32 & 4.82 & 2.83 & \\
10 & Dobrzyca. & 8.38 & 6.16 & 4.75 & 5.58 & \\
11 & Piława & 4.92 & 5.82 & & & \\
12 & Połączone & 8.54 & 7.11 & 5.15 & 3.04 & 2.70 \\
13 & Płytnica & 5.27 & 5.08 & & & \\
14 & Czernica & 8.06 & 5.79 & 3.18 & & \\
15 & Brda & 9.12 & 7.59 & 2.88 & 1.99 & \\
16 & Wda & 7.53 & 5.82 & 4.49 & 2.84 & \\
17 & Gościnka & 6.61 & & & & \\
18 & Supina & 8.30 & 6.41 & & & \\
\hline $\bar{x}$ & & 7.76 & 6.33 & 4.01 & 3.31 & 2.70 \\
\hline & & & & & & \\
\hline
\end{tabular}

Płytnica, Połączone, Czernica), and the lowest (below 0.8) in the graylings from Gościnka, Słupia, Wieprza and Radunia (tab. 7). Because the material was collected mainly in autumn and early winter seasonal changes of that coefficient could not be traced.

\section{Dependence between body weight and total length}

The dependence between/body weight (w) and length (TI) in graylings was calculated only for the most numerous samples obtained from the rivers: Wda, Dobrzyca, Grabowa and Radunia. The equations describing it are presented in fig. 4. It follows from the figure that the highest weight increments were attained by the graylings from Wda and Radunia.

\section{DISCUSSION}

The European grayling is a short-lived species. In Central and South Europe most individuals reach the age of 3-4 years (Błachuta 1987, Gertychowa 1976., Persat 1976, Solewski 1960, 1963), and only a small fraction lives 5-8 years (Aganovic 1965, Balon 


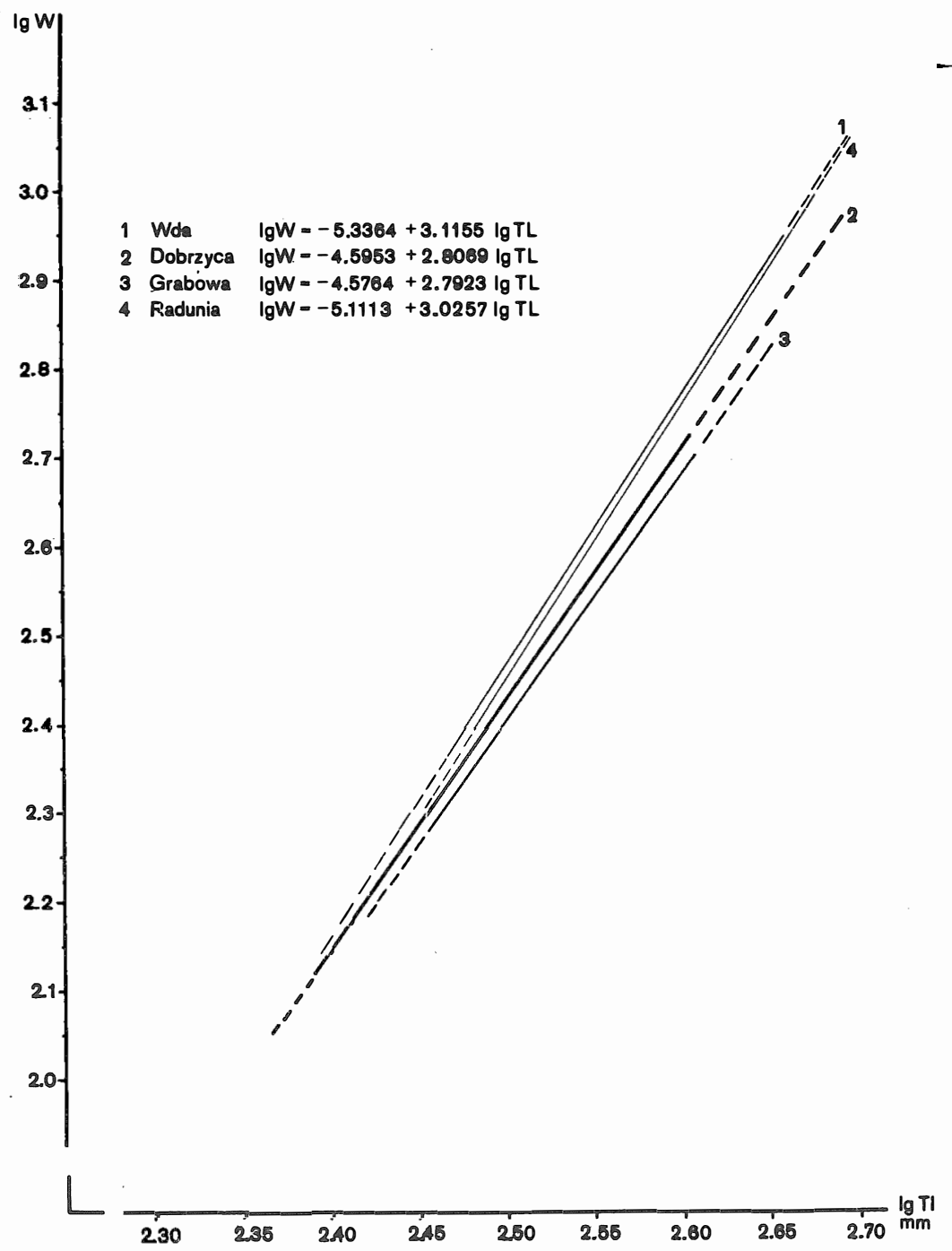

Fig. 4. Dependence between weight (w) and length (Tl) of grayling from Pemeranian rivers. Calculations were made only for the most numerous samples. 
1962, Lusk 1975, Woolland, Jones 1975). As a rule, long-lived populations are found at higher geographic latidudes - in Scandinavia and Karelia - which is associated with later attainement of sexual maturity. In those areas the graylings may reach even the age, of 13-15 years (Müller 1961, Peterson 1968, Vladimirskaya 1957). No fish that old has been found in the material examined. The age structure of graylings from the Pomeranian rivers is similar to that of many populations from Central Europe. The oldest individual was seven years old $\left(6^{+}\right)$. Fish at the age of $2^{+}$and $3^{+}$constituted the highest percentage. Compared to other Polish populations the Pomeranian graylings live semewhat longer. It follows from the data of Penczak et al. (1986) that fish aged $5^{+}$constitute as much as $10.2 \%$ studied populations (Piława + Dobrzyca). In the studied material the percentage of fish at the age of six $\left(5^{+}\right)$and seven $\left(6^{+}\right)$years was also distinctly higher than in the basins of Dunajec, Nysa Kłodzka, Kaczawa and Soła (Błachuta 1987, Gertychowa 1976, Krajewski 1986, Solewski 1960, Witkowski 1975). This results probably from tw facts: a higher geographic latitude and an angling pressure lower than in the sou th of Poland.

The growth rats in grayling depends on various environment factors, both biotic and abiotic. Błachuta (1987), Persat, Patte (1981) are of opinion that beside the water temperature, the growth rate is significantly :nfluenced by the size of the river. In small rivers the graylings attain as a rule a much smaller size than in larger. According to

Table 7

Values of condition coefficient $(\mathrm{K})$ in grayling from Pomeranian rivers

\begin{tabular}{|l|l|l|c|}
\hline No & River & $\mathrm{K}$ & $\mathrm{K}_{\text {min. }}-\mathrm{K}_{\text {max. }}$ \\
\hline 1 & Mołstowa & 0.85 & $0.83-0.86$ \\
2 & Wieprza & 0.78 & $0.75-1.02$ \\
3 & Grabowa & 0.93 & $0.55-1.29$ \\
4 & Słupia & 0.77 & $0.73-0.85$ \\
5 & Eupawa & 0.80 & $0.75-0.87$ \\
6 & Eeba & 0.80 & $0.66-1.04$ \\
7 & Radunia & 0.79 & $0.63-1.00$ \\
8 & Drawa & 0.97 & $0.93-1.00$ \\
9 & Gwda & 0.91 & $0.79-1.10$ \\
10 & Dobrzyca & 0.82 & $0.81-1.04$ \\
11 & Piława & 1.14 & $1.08-1.20$ \\
12 & Połączone & 1.10 & $0.84-1.30$ \\
13 & Płytnica & 1.11 & 1.11 \\
14 & Czernica & 1.07 & $0.93-1.20$ \\
15 & Brda & 0.80 & 0.80 \\
16 & Wda & 0.92 & $0.73-1.22$ \\
17 & Gościnka & 0.70 & 0.70 \\
18 & Supina & 0.86 & $0.81-0.89$ \\
\hline
\end{tabular}


Growth rate ( $\mathrm{Tl}$ in $\mathrm{mm}$ ) of the european grayling in various rivers/lakes of Europe

\begin{tabular}{|c|c|c|c|c|c|c|c|c|c|}
\hline \multirow{2}{*}{ Country } & \multirow{2}{*}{ River/lake } & \multicolumn{7}{|c|}{ Age } & \multirow{2}{*}{ Author } \\
\hline & & 1 & 2 & 3 & 4 & 5 & 6 & $7^{\prime}$ & \\
\hline \multirow[t]{5}{*}{ Soviet Union } & Mesna & 81 & 138 & 196 & 242 & 273 & - & - & Svetovidov (1936) \\
\hline & Čunozero & 87 & 143 & 202 & 262 & 297 & 338 & 361 & Vladymirskaya (1957) \\
\hline & Éljavr & 92 & 167 & 246 & 301 & 335 & 370 & 405 & $"$ \\
\hline & Garjušnoje & 85 & 138 & 196 & 250 & 305 & 350 & 375 & $"$ \\
\hline & Kama & 120 & 170 & 230 & 280 & 330 & 390 & - & Zinovev (1962) \\
\hline Norway & various rivers & 50 & 127 & 199 & 292 & 312 & - & - & Bauch (1970) \\
\hline \multirow[t]{3}{*}{ Sweden } & Indasälven & 94 & 172 & 239 & 296 & 349 & 386 & 408 & Peterson (1968) \\
\hline & Pasvigsän & 70 & 149 & 233 & 305 & - & - & - & $"$ \\
\hline & Storsjö & 84 & 159 & 232 & 286 & 317 & - & - & Gustafson (1949) \\
\hline \multirow[t]{3}{*}{ Great Britain } & Llyn Tegid & 120 & 225 & 298 & 358 & 379 & 399 & - & Woolland, Jones (1975) \\
\hline & Dee & 125 & 238 & 303 & 344 & - & - & - & \\
\hline & Test & 159 & 286 & 335 & 387 & 413 & 432 & - & Hutton (1923) \\
\hline \multirow[t]{3}{*}{ France } & Ain & 150 & 294 & 358 & 402 & - & - & - & Persat (1976) \\
\hline & Loue & 144 & 273 & 319 & 360 & - & - & - & $"$ \\
\hline & Ance & 120 & 238 & 316 & 356 & - & - & - & $"$ \\
\hline Belgium & Ourthe & 145 & 235 & 295 & - & - & - & - & Micha (1971) \\
\hline \multirow[t]{2}{*}{ GFR } & Iser & 90 & 180 & 270 & 350 & - & - & - & Bauch (1970) \\
\hline & Iller & 98 & 202 & 290 & 363 & - & - & - & $"$ \\
\hline GDR & Polenz & 180 & 250 & 280 & 300 & 340 & 350 & - & Bauch (1970) \\
\hline \multirow[t]{7}{*}{ Poland } & Kaczawa & 120 & 180 & 215 & 261 & - & - & - & Błachuta (1987) \\
\hline & Nysa Kłodzka & 139 & 212 & 267 & 304 & - & - & - & $"$ \\
\hline & Soła & 112 & 216 & 262 & 302 & - & - & - & Solewski (1960) \\
\hline & Dunajec & 129 & 241 & 306 & 351 & 361 & - & - & Błachuta (1987) \\
\hline & Rogoźnik & 104 & 190 & 246 & - & - & - & - & Solewski (1963) \\
\hline & Pomeranian rivers & 131 & 238 & 303 & 363 & 409 & - & - & authors \\
\hline & Piława + Dobrzyca & 119 & 212 & 282 & 336 & 391 & - & - & Penczak et al. (1986) \\
\hline \multirow[t]{8}{*}{ Czechoslovakia } & Orava & 134 & 252 & 330 & 381 & 408 & - & - & Lusk, Skacel (1978) \\
\hline & Hornad & 117 & 206 & 258 & - & - & - & - & Jedral (1965) \\
\hline & Turiec & 134 & 203 & 256 & 307 & 395 & - & - & Nieslanik (1963) \\
\hline & Poprad & 129 & 204 & 261 & - & - & - & - & Kirka (1975) \\
\hline & Louxka & 142 & 228 & 280 & 317 & 373 & 385 & - & Lusk (1975) \\
\hline & Svratka & 137 & 242 & 300 & 337 & 355 & 358 & - & $"$ \\
\hline & Divoka Orlice & 150 & 238 & 300 & 342 & - & - & - & Hochman (1964) \\
\hline & Vltava & 142 & 200 & 246 & 282 & - & - & - & Naiksatam (1974) \\
\hline \multirow[t]{2}{*}{ Yugoslavia } & Bosna & 160 & 242 & 293 & 324 & 352 & 372 & 385 & Aganovix (1965) \\
\hline & Pliva & 163 & 234 & 288 & 316 & 344 & 364 & 380 & $"$ \\
\hline \multirow[t]{2}{*}{ Austria } & Kleine Erlauf & 124 & 240 & 318 & - & - & - & - & Jungwirth et al. (1980) \\
\hline & Pielach & 121 & 243 & 320 & - & - & - & - & $"$ \\
\hline
\end{tabular}


Witkowski et.al. (1984) the growth rate of European populations of grayling is very diversified. In tab. 8 . the growth of this species at various geographic latittudes is presented. At higher latitudes (Scandinavia, Karelia) the fish grow slower which is associated with the shorter vegetation season. Populations from Central and Western Europe (France, Belgium, Great Britain, some rivers of Czechoslovakia and Yugoslavia), however, are characterized by a very high growih rate. Those from Eastern Europe (Ural) grow distinctly slower (tab. 8).

According to the criteria of the estimate of growth rate accepted for grayling (Witkowski et al. 1984), the growth of the fish in the Pomeranian rivers can be desribed as follows. Populations from Wieprza, Grabowa, Drawa, Gwda, Dobrzyca, Czernica, Brda and Wda are characterized by a very rapid growih, those from Molstowa, Stupia, $\mathbb{E}$, Eupawa, Radunia, Piława and Supina - by a quick growth, those from Plytnica and Gościnka - by a slowi one.

Compared to populations from the south of Poland - Nysa Klodzka, Kaczawa, Sola and Rogoźnik (Błachuta 1987, Krajewski 1986, Solewski 1960, 1963, Witkowski $1975)$ - the graylings from the Pomeranian rivers show a distinctly higher growth rate. Only in the rivers Dunajec and San the growth is similar to that observed in Pomerania (Brachuta 1987, Blachuta Witkowski unpubl. data, Gertychowa 1976).

\section{REFERENCES}

Aganovic M., 1965: Comparative investigation on the nourishment, growth, fextility, and structure of the populations of grayling in the Rivers Bosma and Pliva. God. Biol. Inst. Univ. Sarajevo, 18: $3-109$

Balon $\mathbb{E}_{0} \mathbb{K}_{0}, 1962:$ Age and growth of the spawning shoal of Thymallus thymallus (Linnaeus, 1758) from $\mathbb{R}$ iverine $\mathbb{L}$ ake on the Hnilec $\mathbb{R} i v e r . \mathbb{Z} 001$. Listy, $11: 145-154$.

Bauch Go, 1970: Die einheimischen Sü sswasserfische. Neuman Verlo, Leipzig, pp。1-200.

Biachuta $\mathbb{J}_{0}, 1987$ : Growth and food of grayling, Thymallus thymallus (L.) in annual cycle from the Dunajec, Nysa KKlodzka and Kaczawa Rivers Doct, Disserto, Mus. Nat. Hist. Univ。 Wrocł., pp. 1-51 (in Polish).

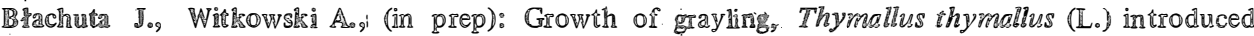
inco the San River. (Typescript), Mus. Nat. Hist. Univ. Wroct. (in Polish)

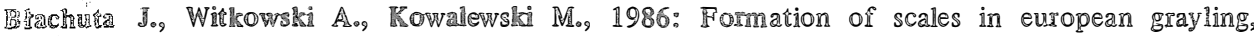
Thymallus thymallus (Lo), Zool Polo, 33:59-70. (in Polish)

Beverton R.Jo, Holt S.J., 1957: On the dynamics of exploited fish populations. U.K. Min. Agr. Fish. Investos, 2

Gertychowa $\mathrm{E}_{\mathrm{N}}, 1976$ : The growth rate of the grayling, Thymallus thymallus $\mathbb{L} .1758$ in the tributaries of the River Dunajec as an indicator of habitat conditions. Ochs. Przyro, $41: 249-280$ (in Polish).

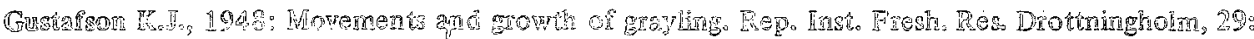
$35-4.40$

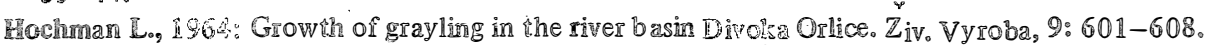

IIutcon J.A., 1923: Something about grayling scales. The Salmon and Trout Mago, 31: 59-64.

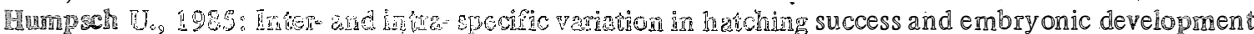

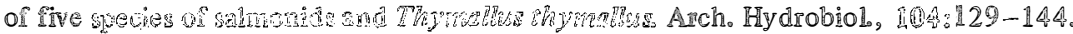


Iwaszkiewicz M., 1962: Sexual muturation and fertility of the grayling, Thymullus thymullus L. from the west Pomeranian Rivers. Zool. Pol., 12: 247-253. (iri Polish)。

Jedral L., 1965: Age and growth of Thymallus thymallus L. in the Hron and Hornad Rivers. Sbor. Vychodoslov. Muz., 6: 69-77.

Jungwirth M., Moog O., Winkler H., 1980: Vergleichende Fischbestands Untersuchungen an elf niederosterreichischen Flussgewasserstrecken. In: Österreichịsche Fischereigesellschaft 1880-1980, Wiener Verlo, Himberg, 81-113.

Kirka A., 1962: Age and growth of Salmo trutta m. fario, Salmo gairdneri irideus, Salvelinus fontinalis and Thymallus thymallus in the brook of Vrica near Klaštor pod Znievom. Pr. Lab. Ryb., 1: 153-161.

Kokurewicz B., Kowalewski M., Witkowski A., 1980: Influence of constant and variable temperatures on the embryonic development of european graylin, Thymallus thymallus (L.). Zool. Pol., 27: 335-362 (in Polish).

Kondracki J., 1980: Physical geography of Poland. PWN, Warszawa, pp. 1-460 (in Polish).

Krajewski J., 1986: The growth of fish (Salmo trutta m. fario. Thymallus thymallus, Phoxinus phoxinus) in Kłodzka Valley waters. Acta Univ. Wratisl, Pr. Zoolo, 15: 3-112. (in Polish).

Lusk S., 1975: Distribution and growth rate of grayling (Thymallus thymallus) in the drainage area of the Svratka River, Czechoslovakia.Zool. Listy, 24: 385-399 (in Czech).

Lusk S., Skacel L., 1978: Grayling. Priroda, Bratislava, pp. 1-182. (in Czech)

Micha J.C., 1971: Densite de population, age et croissance du barbeau, Barbus barbus (L.), et l'ombre, Thymallus thymallus (L.), dans L'Ourthe. Ann. Hydrobiol., 2: 47-68.

Müller K., 1961: Die Biologie der Äsche (Thymallus thymallus L.) imLule Älvo (Swedische Lappland). Zeitschr. f. Fisch. u.d. Hildswiss., 10: 173-201.

Naiksatam A.S., 1974: Age and growth of the European grayling, Thymallus thymallus (Linnaeus, 1758) (Osteichthyes: Thymallidae) from upper Vltava River of Czechoslovakia. Vest. Cesk. Spol。 Zool., 38: 106-112 (in Czech).

Nieslanik J., 1963: Jak rychle roste ryba? Lipan. Česk. Ryb., 18: 112 (in Czech).

Penczak T., Lobon-Cervia J., O’Hara K., Jakubowski H.; 1986: Production and food consumption by fish populations in the Piława and Dobrzyca Rivers, North Poland. Pol. Arch. Hydrobiol., 33: 345-373 (in P.olish).

Persat H., 1976: Principaux aspects de l'ecologie de l'ombre common Thymallus thymallus (L., 1758) (Poissons, Salmonides). Dept. Biol. Anim. Zool., Lyon, 584: 1-69.

Persat H., Pattee E., 1981: The growth rate of young grayling in some French rivers. In: Sladecek, ed. Proc. Internat. Assoc. Theoret. Appl。Limnology, 21: 1270-1275.

Peterson H.H., 1.968: The grayling, Thymallus thymallus (L.) of the Sundsvall Bay area. Rep. Inst. Fresh. Rès. Drottningholm, 48: 36-56.

Rembiszewski J.M., Rolik H., 1975: Catalogus faunae Poloniae. 38. Cyclostomate et Pisces. PWN, Warszawa, pp. 12 252 (in Polish)。

Solewski W., 1960: Die Äsche (Thymallus thymallus L.) des Flussgebietes der Soła. Acta Hydrobiol., 2: 201-220 (in Polissh)。

Solewski W., 1963: The grayling (Thymallus thymallus L.) of the Rogoźnik stream. Acta Hydrobiol., 5: 229-243 (in Polish).

Svetovidov A.N., 1936: Graylings, genus Thymallus Cuvier, of Europe and Asia. Trav. Inst. Zool. Acad. Sci. URSS, 3: 183-301. (in Russian).

Vladimirskaya MoI., 1957: Grayling from lakes of the northwest region of the Lake Imandra basin. Zool. Zhurn., 36: 729-736 (in Russian).

Witkowski A., 1975: The grayling, Thymallus thymallus (L.) from therivers of Lower Silesia, Poland. Acta Hydrobiolo, 17: 355-370 (in Polish). 
Witkowski A., Kowalewski M., Kokurewicz B., 1984: Grayling. PWRiL, Warszawa, pp. 1-214 (in Polish).

Woolland J.V., Jones J.W., 1975: Studies on grayling, Thymallus thymallus L., in Llyn Tegid and the upper River Dee, North Wales. Part I. Age and growth. J. Fish Biolo, 7: 749-773.

Zinovev. E.A., 1962: The biology of grayling of the middle Kama. Ǔ. Zap. Pèrm. Gos. Univ., 22: 147:153 (in Russian).

Andrzej Witkowski, Jan Błachuta, Jolanta Olesińska

\section{WIEK I TEMPO WZROSTU LIPIENIA THYMALLUS THYMALLUS (L.) \\ W RZEKACH POMORZA}

\section{STRESZCZENIE}

W oparciu o materiały liczące 308 osobników lipieni złowionych w 18 rzekach Pomorza przeprowadzono analizę ich wieku oraz dokonano oceny tempa wzrostu.

Z przeprowadzonych badań wynika, że populacje lipieni w tym regionie żyją dłużej oraz rosną szybciej niż w rzekach o podgórskim i górskim charakterze z południa Polski. Wzrost większości badanych populacji można ocenić jạko bardzo szybki i szybki (wg kryteriów ustalonych przez Witkowskiego et al. 1984). Intensywność wzrostu wyraz̊ona wskaźnikiem charakterystyki wzrostu jest największa w okresie juwenilnym (do momentu osiągnięcia dojrzałości płciowej).W późniejszych okresach (adult, senectiv') wyraźnie maleje. Największe wartości współczynnika kondycji obserwuje się u populacji najszybciej rosnących (dorzecze Gwdy), co wskazuje, że w rzekach tego systemu lipień znajduje optymalny układ czynników abiotyczno-biotycznych.

Author's address:

Received: 1989.12 .22

Doc. dr hab. Andrzej Witkowski

Dr Jan Błachuta

mgr Jolanta Olesińska

Wrock aw University, Museum of Natural History

Sienkiewicza 21, 50-335 Wrocław, Poland 